\title{
Sea-to-air and diapycnal nitrous oxide fluxes in the eastern tropical North Atlantic Ocean
}

\author{
A. Kock ${ }^{1}$, J. Schafstall ${ }^{2}$, M. Dengler ${ }^{2}$, P. Brandt ${ }^{2}$, and H. W. Bange ${ }^{1}$ \\ ${ }^{1}$ Forschungsbereich Marine Biogeochemie, Helmholtz-Zentrum für Ozeanforschung Kiel (GEOMAR), Germany \\ ${ }^{2}$ Forschungsbereich Ozeanzirkulation und Klimadynamik, Helmholtz-Zentrum für Ozeanforschung Kiel (GEOMAR), \\ Germany \\ Correspondence to: A. Kock (akock@geomar.de)
}

Received: 12 October 2011 - Published in Biogeosciences Discuss.: 20 October 2011

Revised: 23 February 2012 - Accepted: 23 February 2012 - Published: 7 March 2012

\begin{abstract}
Sea-to-air and diapycnal fluxes of nitrous oxide $\left(\mathrm{N}_{2} \mathrm{O}\right)$ into the mixed layer were determined during three cruises to the upwelling region off Mauritania. Sea-to-air fluxes as well as diapycnal fluxes were elevated close to the shelf break, but elevated sea-to-air fluxes reached further offshore as a result of the offshore transport of upwelled water masses. To calculate a mixed layer budget for $\mathrm{N}_{2} \mathrm{O}$ we compared the regionally averaged sea-to-air and diapycnal fluxes and estimated the potential contribution of other processes, such as vertical advection and biological $\mathrm{N}_{2} \mathrm{O}$ production in the mixed layer. Using common parameterizations for the gas transfer velocity, the comparison of the average sea-toair and diapycnal $\mathrm{N}_{2} \mathrm{O}$ fluxes indicated that the mean sea-toair flux is about three to four times larger than the diapycnal flux. Neither vertical and horizontal advection nor biological production were found sufficient to close the mixed layer budget. Instead, the sea-to-air flux, calculated using a parameterization that takes into account the attenuating effect of surfactants on gas exchange, is in the same range as the diapycnal flux. From our observations we conclude that common parameterizations for the gas transfer velocity likely overestimate the air-sea gas exchange within highly productive upwelling zones.
\end{abstract}

\section{Introduction}

Nitrous oxide $\left(\mathrm{N}_{2} \mathrm{O}\right)$ is a potent greenhouse gas with a major contribution of oceanic emissions to its atmospheric budget (Denman et al., 2007). It is produced in the oxic subsurface and deep ocean during microbial nitrification, whereas in anoxic to suboxic parts of the ocean $\mathrm{N}_{2} \mathrm{O}$ can be produced and/or consumed during canonical denitrification (see e.g. Castro-Gonzalez and Farias, 2004; Nicholls et al., 2007).
While large parts of the surface ocean are close to equilibrium with the atmosphere, enhanced emissions are observed during coastal upwelling events due to the transport of $\mathrm{N}_{2} \mathrm{O}$ enriched subsurface waters into the mixed layer (ML, see e.g. Nevison et al., 2004). Pronounced coastal upwelling in the eastern tropical North Atlantic Ocean (ETNA) occurs seasonally along the coasts of Mauritania and Senegal. Consistently, $\mathrm{N}_{2} \mathrm{O}$ emissions are found to be enhanced during winter/spring (Wittke et al., 2010).

In this study we quantify the diapycnal and sea-to-air fluxes of $\mathrm{N}_{2} \mathrm{O}$ in the ETNA (incl. the upwelling off Mauritania) to estimate the contribution of diapycnal mixing to the $\mathrm{N}_{2} \mathrm{O}$ ML budget: $\mathrm{N}_{2} \mathrm{O}$ concentrations in the ML should, at steady state, represent the balance between physical processes such as vertical mixing, air-sea gas exchange with the overlying atmosphere, vertical and horizontal advection and, potentially, biological processes such as nitrification. The relative importance of the different terms for the $\mathrm{N}_{2} \mathrm{O} M L$ budget is discussed. It is found that diapycnal and sea-to-air fluxes are the leading terms in the $\mathrm{N}_{2} \mathrm{O}$ ML budget and seato-air fluxes are likely overestimated when using common parameterizations for the gas transfer velocity.

\section{Study site}

The investigated area covers the ETNA between the Cape Verde Islands and coast of Mauritania (Fig. 1). A lack of river inputs combined with a narrow continental shelf minimizes additional contributions of $\mathrm{N}_{2} \mathrm{O}$ originating from riverine or sedimentary sources. The Mauritanian upwelling system is the most productive southern branch of the Canary Current upwelling system (Minas et al., 1982; Signorini et al., 1999), showing a seasonality which follows the shifting of the Inter-Tropical Convergence Zone (ITCZ) throughout 

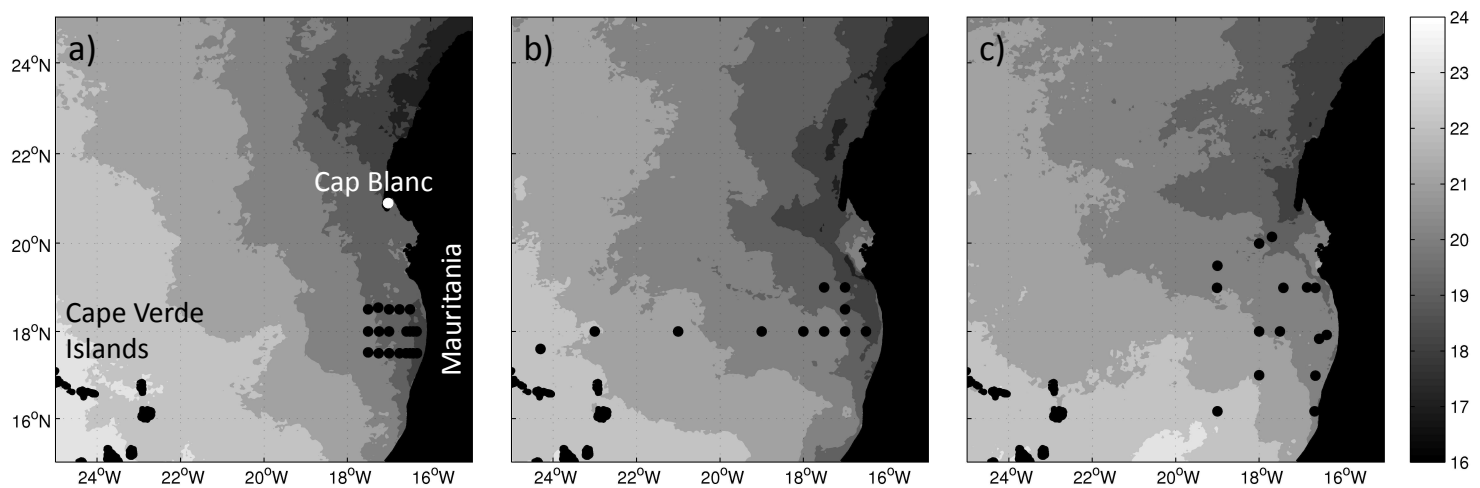

Fig. 1. Map with locations of the sampled stations during P347 in January 2007 (a), P348 in February 2007 (b) and ATA3 in February 2008 (c). MODIS monthly sea surface temperatures (in ${ }^{\circ} \mathrm{C}$ ) are also shown (http://oceandata.sci.gsfc.nasa.gov/MODISA/Mapped/). CVI stands for Cape Verde Islands.

the year (Hagen, 2001). In the region between Cap Vert $\left(\sim 15^{\circ} \mathrm{N}\right)$ and Cap Blanc $\left(\sim 21^{\circ} \mathrm{N}\right)$ seasonal upwelling takes place during winter/spring (Schemainda et al., 1975). Compared to other eastern boundary upwelling systems, the water column in the ETNA has relatively high oxygen concentrations: minimum oxygen concentrations reach down to $40 \mu \mathrm{moll}^{-1}$ (Stramma et al., 2008). We thus conclude that the main production pathway for $\mathrm{N}_{2} \mathrm{O}$ in this region is nitrification.

\section{Methods}

$\mathrm{N}_{2} \mathrm{O}$ concentration, microstructure and conductivitytemperature-depth (CTD) measurements were conducted during three cruises to the ETNA (Fig. 1). The cruises were part of the German BMBF joint project SOPRAN (Surface Ocean Processes in the Anthropocene, www.sopran.pangaea.de) and the DFG-funded Mauritanian upwelling and mixing process study (MUMP). They were scheduled in the upwelling season in January/February 2007 (R/V Poseidon cruises P347 and P348) and February 2008 (R/V L'Atalante cruise ATA3). Water samples were analyzed for dissolved $\mathrm{N}_{2} \mathrm{O}$ on board using a GC/ECD system (Hewlett Packard 5890 II during ATA3, Carlo Erba HRGC 5160 Mega Series during P347 and P348) with a static equilibration method. The GCs were equipped with a $6^{\prime} 1 / 8^{\prime \prime}$ stainless steel column packed with molecular sieve

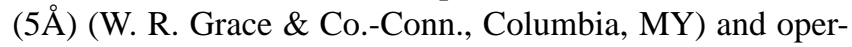
ated at a constant oven temperature of $190^{\circ} \mathrm{C}$ (HP 5890II) and $220^{\circ} \mathrm{C}$ (Carlo Erba HRGC 5160). Argon-methane (95/5, 5.0, AirLiquide, Düsseldorf, Germany) was used as carrier gas at a flow rate of $30 \mathrm{ml} \mathrm{min}^{-1}$. Triplicates of bubble free samples were drawn from 101 Niskin bottles mounted on a CTD/rosette, poisoned with mercuric chloride or measured within $24 \mathrm{~h}$ after sampling. For analysis, a $10 \mathrm{ml}$ helium headspace was added to each sample using a gas-tight syringe (VICI Precision Sampling, Baton Rouge,
LA). A $9.5 \mathrm{ml}$ subsample of the headspace was analyzed for nitrous oxide after an equilibration time of minimum $2 \mathrm{~h}$. The GC was calibrated on a daily basis using at least two different standard gas mixtures (Deuste Steininger $\mathrm{GmbH}$, Mühlheim, Germany) to account for potential drift of the detector. The concentration of $\mathrm{N}_{2} \mathrm{O}$ in the water phase was calculated using the solubility function of $\mathrm{N}_{2} \mathrm{O}$ from Weiss and Price (1980). The average precision of the measurements, calculated from error propagation, was $\pm 0.7 \mathrm{nmoll}^{-1}$.

$\mathrm{N}_{2} \mathrm{O}$ sea-to-air fluxes $F_{\text {sta }}$ (in $\mathrm{nmol} \mathrm{m} \mathrm{m}^{-2} \mathrm{~s}^{-1}$ ) were calculated from the gas exchange equation:

$F_{\text {sta }}=k_{w} \cdot \Delta \mathrm{N}_{2} \mathrm{O}=k_{w} \cdot\left(\left[\mathrm{N}_{2} \mathrm{O}\right]_{w}-\left[\mathrm{N}_{2} \mathrm{O}\right]_{a}\right)$

where $k_{w}$ is the gas transfer velocity and $\left[\mathrm{N}_{2} \mathrm{O}\right]_{w}$ is the measured in-situ concentration from the shallowest Niskin bottle in the surface layer $(5-10 \mathrm{~m})$. The $\mathrm{N}_{2} \mathrm{O}$ equilibrium concentration $\left[\mathrm{N}_{2} \mathrm{O}\right]_{a}$ was calculated by using a mean dry mole fraction of $321 \mathrm{ppb}$ (extracted from the monthly time series of atmospheric $\mathrm{N}_{2} \mathrm{O}$ from the AGAGE monitoring station Ragged Point on Barbados; see http://agage.eas.gatech.edu; Prinn et al., 1990) and the temperature and salinity at the depth of the corresponding Niskin bottle. $k_{w}$ was calculated using the $k_{w}$ /wind speed relationships as defined by Nightingale et al. (2000), Liss and Merlivat (1986) and Wanninkhof (1992) (Fig. 2). Wind speeds were obtained from the ships' underway observations for the calculation of the sea-to-air flux at the individual stations. For the calculation of regionally averaged sea-to air fluxes, we used three day mean QuikScat wind speeds (ftp://ftp.ssmi.com/qscat/).

Alternatively, the sea-to-air flux densities were calculated using the gas transfer velocity parameterization from Tsai and Liu (2003) that takes into account the reduction of the air-sea gas exchange due to surfactants (Fig. 2).

Ocean turbulence profiles were sampled using different microstructure profiling systems (MSS) manufactured by Sea $\&$ Sun Technology. The MSS consists of a loosely-tethered 


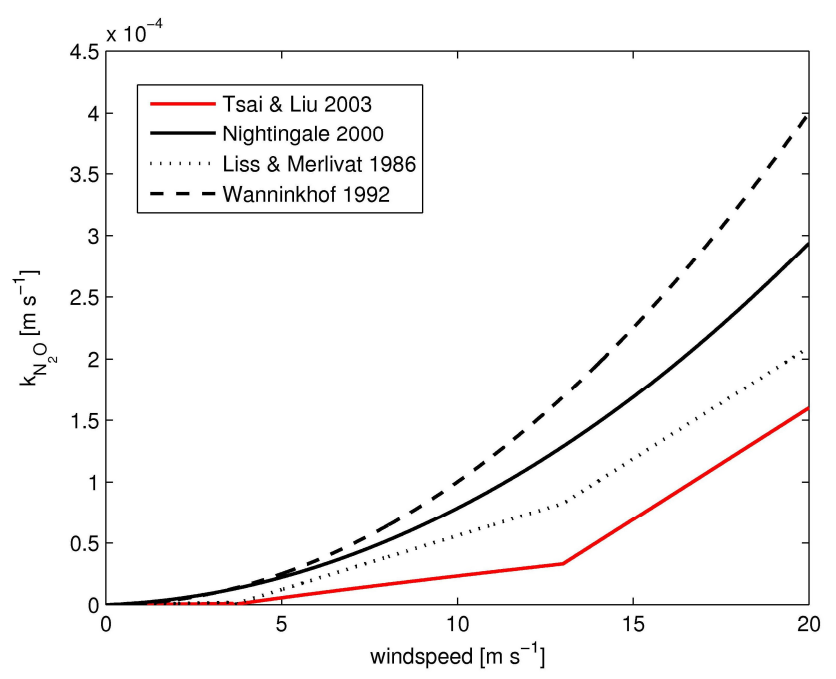

Fig. 2. Wind speed parameterizations used for the calculation of sea-to-air fluxes of $\mathrm{N}_{2} \mathrm{O}$. The black lines represent gas exchange parameterizations for conditions without surfactants while the red line represents the parameterization of Tsai and Liu (2003) for surfactant-influenced surface waters.

profiler, a winch with a cable drum attached to the bulwark and a deck unit. The profilers used during the different cruises were equipped with two shear sensors (airfoil), a fast temperature sensor (FP07), an acceleration sensor, tilt sensors and standard CTD sensors. They were adjusted to descent at a rate of $0.5-0.6 \mathrm{~ms}^{-1}$ while the system records data from 16 channels at $1000 \mathrm{~Hz}$. A detailed description of the instruments is given in Prandke and Stips (1998).

From the high-resolution shear measurements the dissipation rates of turbulent kinetic energy $(\varepsilon)$ were determined by integrating vertical wavenumber spectra of individual onesecond ensembles assuming isotropy of turbulence at scales smaller than $0.6 \mathrm{~m}$. Correction for unresolved spectral ranges and finite sensor tips were applied. For a detailed description of the algorithms used and the instrumental set up during the cruises the reader is referred to Schafstall et al. (2010).

Estimates of diapycnal $\mathrm{N}_{2} \mathrm{O}$ fluxes into the ML we calculated from the station-average diapycnal diffusivities derived from the microstructure measurements from $5 \mathrm{~m}$ below the ML depth to the depth of the next deeper $\mathrm{N}_{2} \mathrm{O}$ water sample. Three to eight microstructure profiles were typically sampled at an individual station. ML depth was determined using the density criterion described by Kara et al. (2000). To avoid any influence from turbulence caused by the ship, the minimum ML depth was set to be at least $15 \mathrm{~m}$ deep. The diapycnal diffusivity $K_{\rho}$ was computed according to Osborn (1980) as

$K_{\rho}=\Gamma \frac{\varepsilon}{N^{2}}$,

and the diapycnal fluxes $F_{\text {dia }}$ of $\mathrm{N}_{2} \mathrm{O}$ as

$F_{\text {dia }}=K_{\rho} \cdot \frac{d\left[\mathrm{~N}_{2} \mathrm{O}\right]}{d z}$, with the local buoyancy frequency $N$ and the mixing efficiency $\Gamma$ which was set to a constant value of 0.2 (Oakey, $1982)$ and the vertical concentration gradient $d\left[\mathrm{~N}_{2} \mathrm{O}\right] / d z$.

The local buoyancy was calculated from the profilers' CTD measurements. Diapycnal $\mathrm{N}_{2} \mathrm{O}$ fluxes were determined only from those microstructure profiles which were recorded concurrently with $\mathrm{N}_{2} \mathrm{O}$ profile sampling.

\section{Results and discussion}

To illustrate the $\mathrm{N}_{2} \mathrm{O}$ sea-to-air and diapycnal fluxes the estimates from the individual stations were projected onto the distribution of topography along $18^{\circ} \mathrm{N}$ (Fig. 3). For this comparison, wind speeds from the ship's underway measurements were used to evaluate sea-to air fluxes. It should be noted that the comparison implicitly assumes that the mean fluxes have larger cross-shore than along-shore gradients, which was shown to be the case in the Mauritanian upwelling region by Schafstall et al. (2010).

The $\mathrm{N}_{2} \mathrm{O}$ sea-to-air fluxes using the Nightingale et al. (2000) parameterization ranged from -0.02 to $0.5 \mathrm{nmol} \mathrm{m}^{-2} \mathrm{~s}^{-1}$ (Fig. 3). Highest fluxes were found close to the shelf break in the zone of active upwelling indicated by low sea surface temperatures (SST). $\mathrm{N}_{2} \mathrm{O}$ sea-to-air fluxes decreased with distance from the shelf break, which can be explained by a combination of continuous outgassing from $\mathrm{N}_{2} \mathrm{O}$-enriched waters and its offshore transport within cold filaments. The majority of the fluxes are positive indicating a flux of $\mathrm{N}_{2} \mathrm{O}$ from the ocean to the atmosphere. However, we also computed negative fluxes which denote a $\mathrm{N}_{2} \mathrm{O}$ flux from the atmosphere into the ocean. These negative fluxes correspond to $\Delta \mathrm{N}_{2} \mathrm{O}$ values of max. $-0.3 \mathrm{nmoll}^{-1}$ and are therefore within the uncertainty range of the measurements.

The open ocean sea-to-air fluxes (west of $18^{\circ} \mathrm{W}$ ) are in agreement with the fluxes computed by Walter et al. (2006). The coastal fluxes between $18^{\circ}$ and $16^{\circ} \mathrm{W}$ are, despite resulting from a different approach, in reasonable agreement with the model-adjusted sea-to-air fluxes computed by Wittke et al. (2010). Rees et al. (2011) calculated sea-to-air fluxes from upwelling filaments of the Mauritanian upwelling in a similar range to our results. Compared to other coastal upwelling systems, the average $\mathrm{N}_{2} \mathrm{O}$ fluxes from the Mauritanian upwelling are relatively low (Charpentier et al., 2010; Bange et al., 1996).

The majority of the diapycnal $\mathrm{N}_{2} \mathrm{O}$ fluxes were lower than the $\mathrm{N}_{2} \mathrm{O}$ sea-to-air fluxes from the Nightingale et al. (2000) parameterization. Largest diapycnal fluxes were found in a narrow band in the region of the shelf break. However, enhanced fluxes were also encountered in the lower shelf region. Since the vertical $\mathrm{N}_{2} \mathrm{O}$ gradients were rather uniform, the variability of diapycnal fluxes is predominately due to the variability of diapycnal diffusivities $\left(K_{\rho}\right)$. As shown by Schafstall et al. (2010), diapycnal mixing along the upper continental slope and the lower shelf region of the 


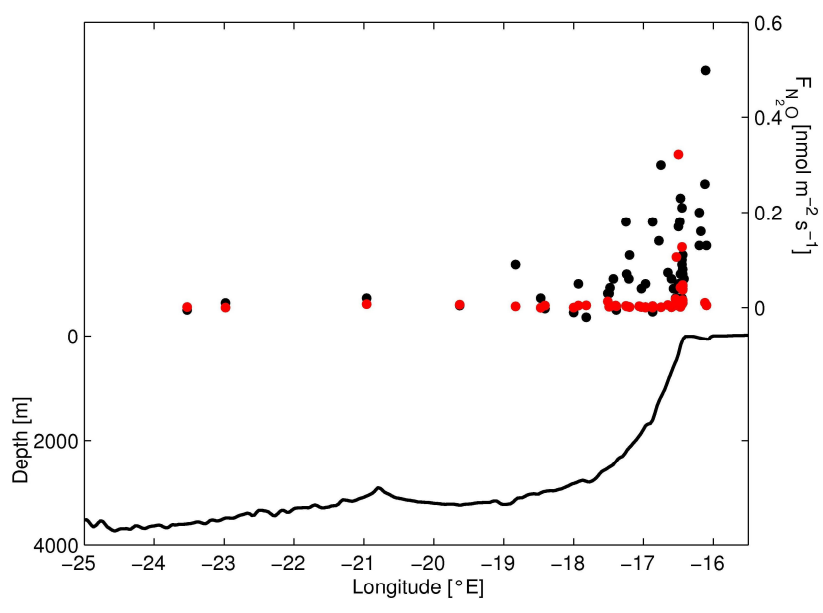

Fig. 3. Diapycnal $\mathrm{N}_{2} \mathrm{O}$ (red dots, right axis) and sea-to-air fluxes (black dots, right axis) projected to $18^{\circ} \mathrm{N}$ and bottom depth along $18^{\circ} \mathrm{N}$ (solid line, left axis). Fluxes from stations to the north and south of $18^{\circ} \mathrm{N}$ were projected onto $18^{\circ} \mathrm{N}$ according to their distance from the $400 \mathrm{~m}$ isobath.

Mauritanian upwelling is strongly enhanced due to presence of non-linear internal tides that form due to critically sloping topography (e.g. Holloway, 1985). Diapycnal nutrient fluxes calculated for the upwelling region are amongst the highest reported to date (Schafstall et al., 2010). Nevertheless, diapycnal $\mathrm{N}_{2} \mathrm{O}$ fluxes from other coastal upwelling regions reported by Charpentier et al. (2010) are in the same order of magnitude as the diapycnal fluxes inferred here.

To determine regional averages of the $\mathrm{N}_{2} \mathrm{O}$ sea-to-air fluxes, the individual station estimates were extrapolated exploiting the dependence of surface $\Delta \mathrm{N}_{2} \mathrm{O}$ on SST anomaly (Fig. 4). For this we used eight day mean MODIS Aqua SST data (http://oceandata.sci.gsfc.nasa.gov/MODISA/Mapped/ 8 Day $/ 4 \mathrm{~km} / \mathrm{SST} /$ ) that covered the sampling periods.

The calculations were performed for an upwelling box off the Mauritanian coast. The size of the box was defined by the northernmost and southernmost sampled station, that is $20^{\circ} 10^{\prime} \mathrm{N}$ and $16^{\circ} 10^{\prime} \mathrm{N}$ respectively, the Mauritanian coastline (except the Banc D'Arguin with bottom depths $<10 \mathrm{~m}$ ) and a line parallel to the shelf break located $170 \mathrm{~km}$ offshore. The SST anomaly was defined as the difference between the SST at a respective position in the upwelling box and the background SST averaged along a $100 \mathrm{~km}$ long section to the west of the box, thereby taking into account its mean latitudinal dependence.

Negative SST anomalies (SSTA) were significantly correlated with $\Delta \mathrm{N}_{2} \mathrm{O}\left(r^{2}=0.54, n=45\right.$; Fig. 4). A linear regression was used to calculate the regional surface $\Delta \mathrm{N}_{2} \mathrm{O}$ distribution from the SSTA $\left(\Delta \mathrm{N}_{2} \mathrm{O}=C \cdot \mathrm{SSTA}\right.$, with the slope of the regression line $C=-2.82 \mathrm{nmoll}^{-1}{ }^{\circ} \mathrm{C}^{-1} . \Delta \mathrm{N}_{2} \mathrm{O}$ values from positive SST anomalies were set to zero, assuming that these values were not influenced by upwelling. The corresponding $\mathrm{N}_{2} \mathrm{O}$ sea-to air fluxes, calculated with the

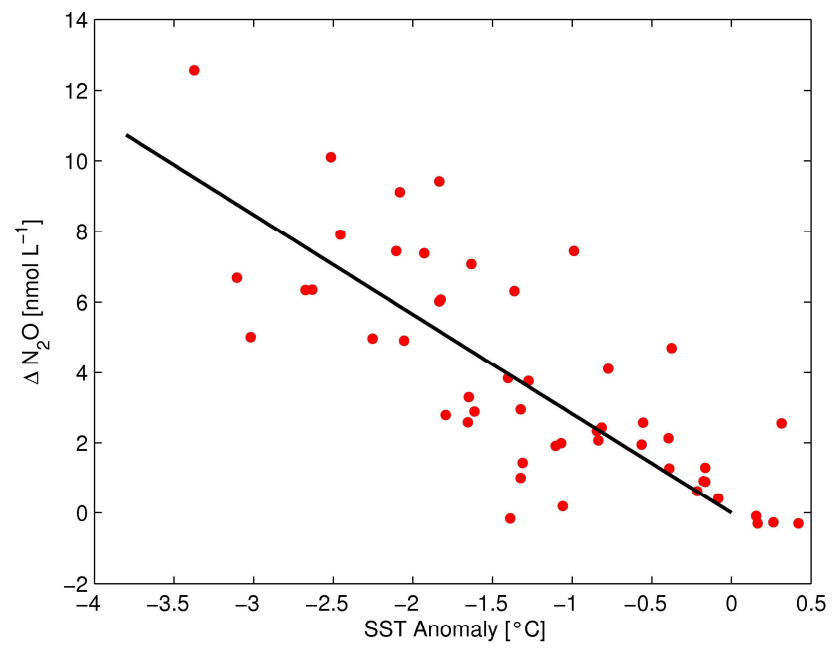

Fig. 4. $\Delta \mathrm{N}_{2} \mathrm{O}$ vs. SST anomaly. The black line denotes the linear regression of $\Delta \mathrm{N}_{2} \mathrm{O}$ with respect to the SST anomaly for SST anomalies smaller than zero.

Nightingale (2000) parameterizantion, were calculated from three day mean QuikScat wind speeds (Fig. 6a). The resulting flux, averaged over the sampling period and the upwelling box, was $0.0685(0.0677$ to 0.0693$) \mathrm{nmol} \mathrm{m}^{-2} \mathrm{~s}^{-1}$. The confidence intervals were calculated using a Monte Carlo simulation with the uncertainties of the $\Delta \mathrm{N}_{2} \mathrm{O}$ calibration and an assumed uncertainty of $\pm 2 \mathrm{~m} \mathrm{~s}^{-1}$ for the wind speed as input variables. To account for the large uncertainties in gas exchange velocities, we additionally calculated sea-to-air fluxes using the gas exchange parameterizations by Liss and Merlivat (1986) and Wanninkhof (1992) as lower and upper boundaries (Wanninkhof et al., 2009) (Table 1).

In contrast to the sea-to-air fluxes, the diapycnal fluxes were averaged in two regions according to their water depths: the shelf (water depth $<400 \mathrm{~m}$ ) and open ocean (water depth $\geq 400 \mathrm{~m}$ ) region (Fig. 5). The average fluxes were $0.07(0.025$ to 0.126$) \mathrm{nmol} \mathrm{m}^{-2} \mathrm{~s}^{-1}$ for the shelf and $0.004(0.002$ to $0.007) \mathrm{nmol} \mathrm{m}^{-2} \mathrm{~s}^{-1}$ for the open ocean region (Fig. 6b). This results in an overall average flux of $0.019(0.007$ to $0.048) \mathrm{nmol} \mathrm{m}^{-2} \mathrm{~s}^{-1}$. Confidence intervals were calculated from error propagation determined from the standard uncertainties of $\varepsilon, N$, mixing efficiency $\gamma$ and the vertical $\mathrm{N}_{2} \mathrm{O}$ gradients as detailed in Schafstall et al. (2010).

Although the diapycnal flux estimate shows large uncertainties and the calculated sea-to-air flux strongly depends on the choice of the gas exchange parameterization, the comparison of the sea-to-air fluxes with the diapycnal flux shows a large discrepancy between the two fluxes. None of the commonly used gas exchange parameterizations is able to adequately close the discrepancy, with the average diapycnal flux only explaining about $25-30 \%$ of the average seato-air flux determined from the Nightingale et al. (2000) parameterization. 
Table 1. Sea-to-air fluxes $\left(F_{\text {sta }}\right)$ of $\mathrm{N}_{2} \mathrm{O}$ calculated with different gas exchange parameterizations and corresponding $\mathrm{N}_{2} \mathrm{O}$ production rates at a ML depth of $25 \mathrm{~m}$ required to compensate the discrepancy between the sea-to-air flux and the sum of diapycnal $\left(F_{\text {dia }}\right)$ and vertical advective $\left(F_{\mathrm{adv}}\right)$ flux.

\begin{tabular}{|c|c|c|c|}
\hline Parameterization & $F_{\text {sta }}\left[\mathrm{nmol} \mathrm{m}^{-2} \mathrm{~s}^{-1}\right]$ & $F_{\mathrm{sta}}-\left(F_{\mathrm{dia}}+F_{\mathrm{adv}}\right)\left[\mathrm{nmol} \mathrm{m}^{-2} \mathrm{~s}^{-1}\right]$ & Required $\mathrm{N}_{2} \mathrm{O}$ production rate $\left[\mathrm{nmol}^{-1} \mathrm{yr}^{-1}\right]$ \\
\hline Nightingale (2000) & $0.069(0.067$ to 0.070$)$ & $0.048(0.018$ to 0.060$)$ & $61(22$ to 76$)$ \\
\hline Liss and Merlivat (1986) & $0.047(0.045$ to 0.047$)$ & $0.026(-0.005$ to 0.038$)$ & $33(-6$ to 47$)$ \\
\hline Wanninkhof (1992) & $0.084(0.082$ to 0.085$)$ & $0.064(0.032$ to 0.076$)$ & $80(41$ to 95$)$ \\
\hline Tsai and Liu (2003) & $0.02(0.019$ to 0.021$)$ & $-0.001(-0.031$ to 0.011$)$ & $-1(-40$ to 14$)$ \\
\hline
\end{tabular}

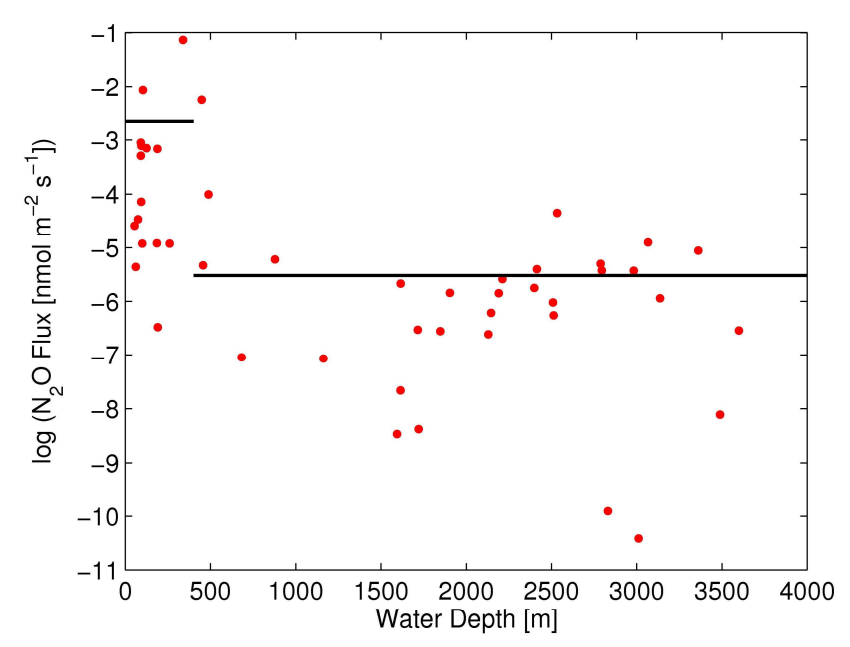

Fig. 5. Diapycnal $\mathrm{N}_{2} \mathrm{O}$ fluxes vs. water depth. The black lines denote average fluxes for the shelf and for the open ocean region.

The missing oceanic flux required to close the $\mathrm{N}_{2} \mathrm{O} \mathrm{ML}$ budget cannot be attributed to vertical advection of $\mathrm{N}_{2} \mathrm{O}$ resulting from Ekman divergence, however. A regional average of the vertical advective flux $\left(F_{\text {adv }}\right)$ calculated from wind stress curl using QuikSCAT winds and $\mathrm{N}_{2} \mathrm{O}$ concentration differences between the ML and the next deeper available value, from 10 to $30 \mathrm{~m}$ below the ML, resulted in $0.0021 \mathrm{nmol} \mathrm{m}^{-2} \mathrm{~s}^{-1}$ (Schafstall, 2010). Vertical advection of $\mathrm{N}_{2} \mathrm{O}$ is thus nearly an order of magnitude lower than the diapycnal flux. Similarly, the horizontal flux divergence associated with a mean $\mathrm{N}_{2} \mathrm{O}$ gradient along the eastern boundary current is not able to close the $\mathrm{N}_{2} \mathrm{O}$ ML budget.

$\mathrm{N}_{2} \mathrm{O}$ production from near-surface nitrification has been previously suggested to close the discrepancy between diapycnal and sea-to-air fluxes (e.g. Dore and Karl, 1996; Santoro et al., 2010). Recent publications have shown that nitrification within the euphotic zone can play a significant role in nutrient cycling of the surface ocean (Clark et al., 2008; Santoro et al., 2010; Wankel et al., 2007; Yool et al., 2007).

Based on the estimates of diapycnal, advective and sea-toair flux we calculated potential $\mathrm{N}_{2} \mathrm{O}$ production rates closing the $\mathrm{N}_{2} \mathrm{O}$ ML budget, assuming a ML depth of $25 \mathrm{~m}$ (Table 1).
Although covering a large range, the calculated $\mathrm{N}_{2} \mathrm{O}$ production rates are extremely high: using the Nightingale (2000) parameterization, the average $\mathrm{N}_{2} \mathrm{O}$ ML production rate must be as high as about $60 \mathrm{nmol} \mathrm{kg}^{-1} \mathrm{yr}^{-1}\left(0.16 \mathrm{nmoll}^{-1} \mathrm{~d}^{-1}\right)$ for a ML depth of $25 \mathrm{~m}$. This exceeds $\mathrm{N}_{2} \mathrm{O}$ production rates in the water column below the ML, quantified to be $\leq 3.3 \mathrm{nmol} \mathrm{kg}^{-1} \mathrm{yr}^{-1}$, by far (Freing et al., 2012). With a molar $\mathrm{N}_{2} \mathrm{O}$ yield during nitrification between 0.5 and $0.01 \%$ (Bange, 2008) the corresponding nitrification rates would range from 30 to $1500 \mathrm{nmoll}^{-1} \mathrm{~d}^{-1}$. This is significantly higher than the nitrification rates of up to $5 \mathrm{nmoll}^{-1} \mathrm{~d}^{-1}$ from ML samples from Mauritanian upwelling region measured by Clark et al. (2008) which, for comparison, would yield an $\mathrm{N}_{2} \mathrm{O}$ flux of $0.001 \mathrm{nmol} \mathrm{m}^{-2} \mathrm{~s}^{-1}$ at a $\mathrm{N}_{2} \mathrm{O}$ yield of $0.1 \%$.

In a more recent publication by Rees et al. (2011), nitrite oxidation rate measurements from two upwelling filaments off Mauritania provide higher nitrification rates in the upper $100 \mathrm{~m}$ of the water column $\left(25 \pm 12 \mathrm{nmoll}^{-1} \mathrm{~d}^{-1}\right.$ and $115 \pm 106 \mathrm{nmoll}^{-1} \mathrm{~d}^{-1}$ for two different filaments), with a tendency to increase with depth and maximum rates at $100 \mathrm{~m}$ depth.

Rees et al. (2011) compared the $\mathrm{N}_{2} \mathrm{O}$ production estimated from their surface water nitrification rates with their sea-toair fluxes and came the conclusion that surface $\mathrm{N}_{2} \mathrm{O}$ production could only explain a small portion of the sea-to-air flux of $\mathrm{N}_{2} \mathrm{O}$. The majority of the $\mathrm{N}_{2} \mathrm{O}$ emissions would have to be supplied from below.

Although these nitrification rates are high enough to make a substantial contribution to our mixed layer budget, this may be due to the different sampling strategy applied by Rees et al. (2011), who followed two upwelling filaments with strongly elevated primary productivity and $\mathrm{N}_{2} \mathrm{O}$ concentrations. In our approach on the other hand we randomly sampled the area without regard to the upwelling conditions, and a large number of our measurements do not indicate pronounced upwelling. The high nitrification rates measured by Rees et al. (2011) are thus not representative for the regional budget estimate presented here. 


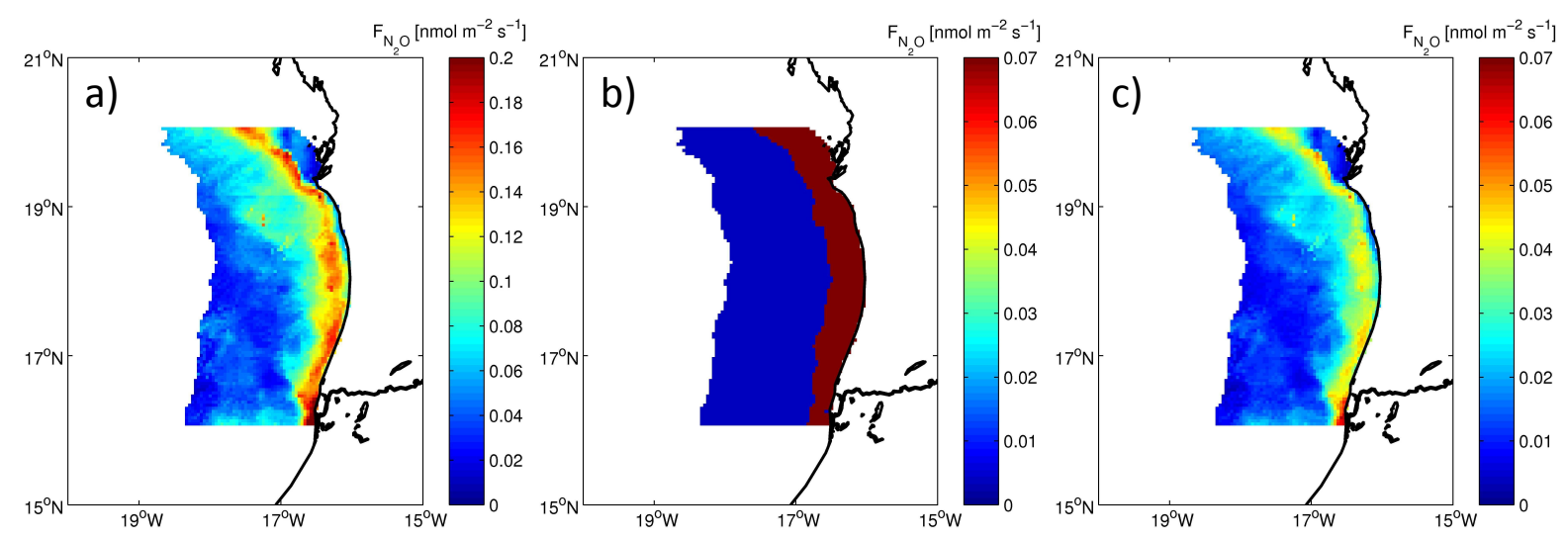

Fig. 6. (a) Regional distribution of the $\mathrm{N}_{2} \mathrm{O}$ fluxes calculated from SST anomalies and averaged over the sampling time using the Nightingale (2000) parameterization. (b) Regional distribution of the diapycnal $\mathrm{N}_{2} \mathrm{O}$ flux. (c) like (a) but using the Tsai and Liu (2003) parameterization. Please note the different scaling of the colorbars in (a) and (b), (c).

Furthermore, their data provide another argument against biological $\mathrm{N}_{2} \mathrm{O}$ production as explanation for the missing $\mathrm{ML} \mathrm{N}_{2} \mathrm{O}$ source: higher nitrification rates at about $100 \mathrm{~m}$ depth compared to the near-surface layer together with the findings that the $\mathrm{N}_{2} \mathrm{O}$ yield increases with decreasing oxygen concentrations (Goreau et al., 1980; Loescher et al., 2012) would result in higher $\mathrm{N}_{2} \mathrm{O}$ production rates at $100 \mathrm{~m}$ than in the near-surface layer. These high subsurface production rates in turn contradict the estimates of ocean interior $\mathrm{N}_{2} \mathrm{O}$ production rates (Freing et al., 2012).

The ML budget could yet be closed using a gas exchange parameterization that takes into account the attenuating effect of surfactants on air-sea gas exchange (Tsai and Liu, 2003).

The resulting average sea-to-air flux for the upwelling box is $0.020 \mathrm{nmol} \mathrm{m}^{-2} \mathrm{~s}^{-1}$ and thus of similar magnitude as the diapycnal flux (Table 1, Fig. 6c).

However, the gas exchange under the influence of surfactants is not well constrained so far, because (a) the distribution of surfactants in natural waters is difficult to determine and (b) the influence of surfactants on gas fluxes is not well understood.

Biological production has been identified as main source for surface slicks (Lin et al., 2002; Wurl et al., 2011), and SeaWiFs chlorophyll images (not shown) show that the investigated area was highly productive during the sampling periods. The occurrence of surfactants was furthermore associated with high intensities of solar radiation (Gasparovic et al., 1998) which can be found in the tropical upwelling areas. Therefore, the Mauritanian upwelling provides very favorable conditions for the occurrence of surfactants while their extent and individual distribution during the time of the sampling may show large variability, though.

The parameterization of Tsai and Liu (2003) is based on the experiments of Broecker et al. (1978), resulting in 70$80 \%$ reduced fluxes for $\mathrm{CO}_{2}$. This is in the upper range of observed reduction rates (Salter et al., 2011; UpstillGoddard, 2006; Schmidt and Schneider, 2011) and may therefore slightly overestimate the reducing effect of surfactants. However, recent publications point to a relatively large effect of surfactants on gas exchange (Schmidt and Schneider, 2011; Salter et al., 2011), and the applicability of the parameterization of Tsai and Liu (2003) for the budget calculation demonstrates that this effect may have a large impact on gas fluxes in upwelling areas.

\section{Summary and conclusions}

For the first time, microstructure measurements were used to estimate the diapycnal flux of nitrous oxide into the ML. The comparison with sea-to-air fluxes shows a different regional distribution due to the offshore transport of the supersaturated surface waters. The regionally integrated average sea-to-air fluxes using standard parameterizations exceed the average diapycnal flux by a factor of three to four. We argue that this discrepancy is unlikely to be explained by biological $\mathrm{N}_{2} \mathrm{O}$ production in the mixed layer or vertical advection alone. Instead, a significantly reduced gas exchange due to the occurrence of surfactants may be a plausible explanation, although there is no direct evidence for a correlation between surfactants and reduced $\mathrm{N}_{2} \mathrm{O}$ fluxes so far. Other effects, including a reduced atmospheric turbulence due to a stably stratified boundary layer over cold upwelling waters or the presence of vertical $\mathrm{N}_{2} \mathrm{O}$ gradients in the oceanic mixed layer due to diurnal varying mixing activity, could also lead to a reduced gas exchange. However, our results suggest that common parameterizations of air-sea gas exchange may lead to a significant overestimation of the oceanic emissions of $\mathrm{N}_{2} \mathrm{O}$ and other trace gases in highly productive areas. 
Acknowledgements. We thank the captains and crews of $\mathrm{R} / \mathrm{V}$ L'Atalante and $\mathrm{R} / \mathrm{V}$ Poseidon for their excellent support during the cruises. Also, we thank A. Freing for inspiring discussions about the $\mathrm{N}_{2} \mathrm{O}$ mixed layer source and A. Körtzinger, B. Fiedler, T. Tanhua, and M. Glessmer for their support during the field work. We would like to thank two anonymous referees for their constructive comments that helped to improve the manuscript. Financial support for this study was provided by DFG grants DE 1369/1-1 and DE 1369/3-1 (JS and MD) and BMBF grant SOPRAN FKZ 03F0462A (AK). QuikScat data are produced by Remote Sensing Systems and sponsored by the NASA Ocean Vector Winds Science Team. Data are available at www.remss.com.

Edited by: M. Voss

\section{References}

Bange, H. W.: Gaseous nitrogen compounds (NO, $\mathrm{N}_{2} \mathrm{O}, \mathrm{N}_{2}, \mathrm{NH}_{3}$ ) in the ocean, in: Nitrogen in the Marine Environment, 2 edn., edited by: Capone, D. G., Bronk, D. A., Mulholland, M. R., and Carpenter, E. J., Academic Press/Elsevier 51-94, 2008.

Bange, H. W., Rapsomanikis, S., and Andreae, M. O.: Nitrous oxide emissions from the Arabian Sea, Geophys. Res. Lett., 23, 31753178, 1996.

Broecker, H. C., Petermann, J., and Siems, W.: Influence of wind on $\mathrm{CO}_{2}$-exchange in a wind-wave tunnel, including effects of monolayers, J. Mar. Res., 36, 595-610, 1978.

Castro-Gonzalez, M. and Farias, L.: N(2)O cycling at the core of the oxygen minimum zone off northern Chile, Mar. Ecol.-Prog. Ser., 280, 1-11, doi:10.3354/meps280001, 2004.

Charpentier, J., Farias, L., and Pizarro, O.: Nitrous oxide fluxes in the central and eastern South Pacific, Global Biogeochem. Cy., 24, Gb3011, doi:10.1029/2008gb003388, 2010.

Clark, D. R., Rees, A. P., and Joint, I.: Ammonium regeneration and nitrification rates in the oligotrophic Atlantic Ocean: Implications for new production estimates, Limnol. Oceanogr., 53, 52-62, 2008.

Denman, K. L., Brasseur, G., Chidthaisong, A., Ciais, P., Cox, P. M., Dickinson, R. E., Hauglustaine, D., Heinze, C., Holland, E., Jacob, D., Lohmann, U., Ramachandran, S., Leite da Silva Dias, P., Wofsy, S. C., and Zhang, X.: Couplings between changes in the climate system and biogeochemistry, in: Climate Change 2007: The Physical Science Basis. Contribution of Working Group I to the Fourth Assessment Report of the Intergovernmental Panel on Climate Change, edited by: Solomon, S., Cambridge University Press, Cambridge, UK and New York, NY, USA, 499588, 2007.

Dore, J. E. and Karl, D. M.: Nitrification in the euphotic zone as a source for nitrite, nitrate, and nitrous oxide at Station ALOHA, Limnol. Oceanogr., 41, 1619-1628, 1996.

Freing, A., Wallace, D., and Bange, H. W.: Global oceanic production of nitrous oxide, Philos, T. R. Soc. Lon. B, in press, doi:10.1098/rstb.2011.0360, 2012.

Gasparovic, B., Kozarac, Z., Saliot, A., Cosovic, B., and Mobius, D.: Physicochemical characterization of natural and ex-situ reconstructed sea-surface microlayers, J. Colloid. Interf. Sci., 208, 191-202, doi:10.1006/jcis.1998.5792, 1998.

Goreau, T. J., Kaplan, W. A., Wofsy, S. C., McElroy, M. B., Valois, F. W., and Watson, S. W.: Production of $\mathrm{NO}_{2}^{-}$and $\mathrm{N}_{2} \mathrm{O}$ by nitrifying bacteria at reduced concentrations of oxygen, Appl. Environ. Microb., 40, 526-532, 1980.

Hagen, E.: Northwest African upwelling scenario, Oceanol. Acta, 24, S113-S127, 2001.

Holloway, P. E.: A comparison of semidiurnal internal tides from different bathymetric locations on the Australian north-west shelf, J. Phys. Oceanogr., 15, 240-251, 1985.

Kara, A. B., Rochford, P. A., and Hurlburt, H. E.: An optimal definition for ocean mixed layer depth, J. Geophys. Res., 105, 1680316821, 2000.

Lin, I. I., Wen, L. S., Liu, K. K., Tsai, W. T., and Liu, A. K.: Evidence and quantification of the correlation between radar backscatter and ocean colour supported by simultaneously acquired in situ sea truth, Geophys. Res. Lett., 29, 1464, doi:10.1029/2001g1014039, 2002.

Liss, P. S. and Merlivat, L.: Air-sea exchange rates: introduction and synthesis, in: The role of air-sea exchange in geochemical cycling, edited by: Buat-Ménard, P., Series C: Mathem. \& Phys. Sciences, D. Reidel Publishing Company, Dordrecht, 113-127, 1986.

Loescher, C. R., Kock, A., Koenneke, M., LaRoche, J., Bange, H. W., and Schmitz, R. A.: Production of oceanic nitrous oxide by ammonia-oxidizing archaea, Biogeosciences Discuss., 9, 20952122, doi:10.5194/bgd-9-2095-2012, 2012.

Minas, H. J., Codispoti, L. A., and Dugdale, R. C.: Nutrients and primary production in the upwelling region off Northwest Africa, Rapports et Procès-Verbaux des Réunions, Conseil International pour L'Exploration de la Mer, 180, 148-182, 1982.

Nevison, C. D., Lueker, T. J., and Weiss, R. F.: Quantifying the nitrous oxide source from coastal upwelling, Global Biogeochem. Cy., 18, GB1018, doi:10.1029/2003GB002110, 2004.

Nicholls, J. C., Davies, C. A., and Trimmer, M.: High-resolution profiles and nitrogen isotope tracing reveal a dominant source of nitrous oxide and multiple pathways of nitrogen gas formation in the central Arabian Sea, Limnol. Oceanogr., 52, 156-168, 2007.

Nightingale, P., Malin, G., Law, C. S., Watson, A. J., Liss, P. S., Liddicoat, M. I., Boutin, J., and Upstill-Goddard, R. C.: In situ evaluation of air-sea gas exchange parameterizations using novel conservative and volatile tracers, Global Biogeochem. Cy., 14, 373-387, 2000.

Oakey, N. S.: Determination of the rate of dissipation of turbulent energy from simultaneous temperature and velocity shear microstructure measurements, J. Phys. Oceanogr., 12, 256-271, 1982.

Osborn, T. R.: Estimates of the local-rate of vertical diffusion from dissipation measurements, J. Phys. Oceanogr., 10, 83-89, 1980.

Prandke, H. and Stips, A.: Test measurements with an operational microstructure-turbulence profiler: Detection limit of dissipation rates, Auquat. Sci., 60, 191-209, 1998.

Prinn, R., Cunnold, D., Rasmussen, R., Simmonds, P., Alyea, F., Crawford, A., Fraser, P., and Rosen, R.: Atmospheric emissions and trends of nitrous-oxide deduced from 10 years of ALEGAUGE data, J. Geophys. Res.-Atmos., 95, 18369-18385, 1990.

Rees, A. P., Brown, I. J., Clark, D. R., and Torres, R.: The Lagrangian progression of nitrous oxide within filaments formed in the Mauritanian upwelling, Geophys. Res. Lett., 38, L21606, doi:10.1029/2011g1049322, 2011.

Salter, M. E., Upstill-Goddard, R. C., Nightingale, P. D., Archer, S. D., Blomquist, B., Ho, D. T., Huebert, B., Schlosser, P., and 
Yang, M.: Impact of an artificial surfactant release on air-sea gas fluxes during Deep Ocean Gas Exchange Experiment II, J. Geophys. Res.-Oceans, 116, C11016, doi:10.1029/2011jc007023, 2011.

Santoro, A. E., Casciotti, K. L., and Francis, C. A.: Activity, abundance and diversity of nitrifying archaea and bacteria in the central California Current, Environ. Microbiol., 12, 1989-2006, doi:10.1111/j.1462-2920.2010.02205.x, 2010.

Schafstall, J.: Turbulente Vermischungsprozesse und Zirkulation im Auftriebsgebiet vor Nordwestafrika, PhD, RD1 - Physical Oceanography, Christian-Albrechts-Universität, Kiel, 219 pp., 2010.

Schafstall, J., Dengler, M., Brandt, P., and Bange, H.: Tidalinduced mixing and diapycnal nutrient fluxes in the Mauritanian upwelling region, J. Geophys. Res.-Oceans, 115, C10014, doi:10.1029/2009jc005940, 2010.

Schemainda, R., Nehring, D., and Schulz, S.: Ozeanologische Untersuchungen zum Produktionspotential der nordwestafrikanischen Wasserauftriebsregion 1970-1973, Akademie der Wissenschaften der Deutschen Demokratischen Republik, Berlin, 1$88,1975$.

Schmidt, R. and Schneider, B.: The effect of surface films on the air-sea gas exchange in the Baltic Sea, Mar. Chem., 126, 56-62, 2011.

Signorini, S. R., Murtugudde, R. G., McClain, C. R., Christian, J. R., Picaut, J., and Busalacchi, A. J.: Biological and physical signatures in the tropical and subtropical Atlantic, J. Geophys. Res.Oceans, 104, 18367-18382, 1999.

Stramma, L., Brandt, P., Schafstall, J., Schott, F., Fischer, J., and Kortzinger, A.: Oxygen minimum zone in the North Atlantic south and east of the Cape Verde Islands, J. Geophys. Res.Oceans, 113, C04014, doi:10.1029/2007jc004369, 2008.
Tsai, W. T. and Liu, K. K.: An assessment of the effect of sea surface surfactant on global atmosphere-ocean $\mathrm{CO}_{2}$ flux, J. Geophys. Res.-Oceans, 108, 3127, doi:10.1029/2000jc000740, 2003.

Upstill-Goddard, R. C.: Air-sea gas exchange in the coastal zone, Estuar. Coast. Shelf S., 70, 388-404, doi:10.1016/j.ecss.2006.05.043, 2006.

Walter, S., Bange, H. W., Breitenbach, U., and Wallace, D. W. R.: Nitrous oxide in the North Atlantic Ocean, Biogeosciences, 3, 607-619, doi:10.5194/bg-3-607-2006, 2006.

Wankel, S. D., Kendall, C., Pennington, J. T., Chavez, F. P., and Paytan, A.: Nitrification in the euphotic zone as evidenced by nitrate dual isotopic composition: Observations from Monterey Bay, California, Global Biogeochem. Cy., 21, Gb2009, doi:10.1029/2006gb002723, 2007.

Wanninkhof, R.: Relationship between wind speed and gas exchange over the ocean, J. Geophys. Res.-Oceans, 97, 7373-7382, 1992.

Wanninkhof, R., Asher, W. E., Ho, D. T., Sweeney, C., and McGillis, W. R.: Advances in Quantifying Air-Sea Gas Exchange and Environmental Forcing, Annu. Rev. Mar. Sci., 1, 213-244, doi:10.1146/annurev.marine.010908.163742, 2009.

Weiss, R. F. and Price, B. A.: Nitrous oxide solubility in water and seawater, Mar. Chem., 8, 347-359, 1980.

Wittke, F., Kock, A., and Bange, H. W.: Nitrous oxide emissions from the upwelling area off Mauritania (NW Africa), Geophys. Res. Lett., 37, L12601, doi:10.1029/2010gl042442, 2010.

Wurl, O., Wurl, E., Miller, L., Johnson, K., and Vagle, S.: Formation and global distribution of sea-surface microlayers, Biogeosciences, 8, 121-135, doi:10.5194/bg-8-121-2011, 2011.

Yool, A., Martin, A. P., Fernandez, C., and Clark, D. R.: The significance of nitrification for oceanic new production, Nature, 447, 999-1002, doi:10.1038/nature05885, 2007. 